\title{
CONCEPT OF JOINT INVESTIGATION TEAMS
}

\author{
Marin Petkov ${ }^{1}$ and Dragomir Krastev ${ }^{2}$, \\ ${ }^{1}$ Assoc. Professor, Ph.D., National Military University, Veliko Tarnovo, Bulgaria, \\ marin_5kov@abv.bg \\ ${ }^{2}$ Assoc. Professor, Ph.D., National Military University, Veliko Tarnovo, Bulgaria, \\ drago.krastev@gmail.com
}

\begin{abstract}
The objective is to provide information, guidance and advice to practitioners on the formation of joint investigation teams (JITs). It was developed by the JITs Network - in cooperation with Eurojust, Europol and OLAF - and enhances the previous JITs manual in light of the acquired practical experience.

The EU legal framework for setting up JITs between Member States can be found in Article 13 of the 2000 EU Mutual Legal Assistance Convention1 and the 2002 Framework Decision on JITs2. All Member States have implemented one or both of these legal bases, to date.
\end{abstract}

Keywords: Eurojust, Europol, OLAF, Joint Investigation Teams.

\section{INTRODUCTION}

A joint investigation team is an international cooperation tool based on an agreement between competent authorities - both judicial (judges, prosecutors, investigative judges...) and law enforcement - of two or more States, established for a limited duration and for a specific purpose, to carry out criminal investigations in one or more of the involved States. Compared to traditional forms of police and judicial cooperation, JITs have the following added value: - JITs enable the direct gathering and exchange of information and evidence without the need of using traditional channels of mutual legal assistance (MLA). Information and evidence collected in accordance with the legislation of the State in which the team operates can be shared on the (sole) basis of the JIT agreement; and - Seconded members of the team (i.e. those originating from a State other than the one in which the JIT operates) are entitled to be present and to take part - within the limits foreseen by national legislation and/or specified by the JIT leader - in investigative measures conducted outside their State of origin. For these reasons, JITs constitute a very efficient and effective cooperation tool, which facilitates the coordination of investigations and prosecutions conducted in parallel across several States.

\section{CONCEPT OF JOINT INVESTIGATION TEAMS}

General issues. To enable the JIT to operate efficiently, JIT partners may wish to agree - if not already included in the JIT agreement itself - on practical arrangements concerning, inter alia, the following issues: 
Investigative objectives (both short- and medium-term);

Exchange of information and evidence: channels of communication and frequency, i.e. use of SIENA available via Europol as a secure means for communication of personal or sensitive information, or secure email available with Eurojust's equipment;

Coordination of investigative measures: frequency and modalities (face-to-face or video-link) of operational briefings;

Role of seconded members: timing and duration of secondment; possible assignments in the State of operation;

Administration and logistics: working language, equipment (office accommodation, vehicles, IT equipment, other), resources, personnel;

Disclosure and admissibility requirements: clarification of respective domestic rules and identification of specific requirements that may be relevant in view of JIT operations;

Financial support: roles and responsibilities for the submission of funding applications and reimbursement requests;

Prosecution strategies: arrangements on jurisdiction, including possible transfer of proceedings.

Crime-specific issues. JIT partners may also wish to consider these additional arrangements for the following offences: Trafficking in human beings: special arrangements for support to victims; Drug trafficking: handling of samples and their further forensic examination, including coverage of expenses; Euro counterfeiting: cooperation with the European Central Bank and/or national banks; also with Europol's Forgery of Money group; Money laundering and asset recovery: coordination of cooperation with third States; specific arrangements to tackle the financial dimension of investigations, arrangements concerning tracing, freezing, confiscation, management and sharing of assets among JIT partners (and, if applicable, with States not involved in the JIT), including the need for urgent measures to prevent dissipation of assets, use of existing networks (such as CARIN and other regional asset recovery networks); Counterfeiting: terms of involvement of private parties; initiation and coordination .of financial investigations; Property crime: storage of seized items, including sharing of storage expenses; Cybercrime: terms of involvement of private parties; involvement of non-EU States; If clarification of specific aspects of different types of offences is required, Europol experts and analysts and Eurojust National Desks can be addressed and solutions can be found during operational/coordination meetings.

Legal Framework. The EU legal framework for setting up JITs between Member States can be found in Article 13 of the 2000 EU Mutual Legal Assistance Convention and the 2002 Framework Decision on JITs. All Member States have implemented one or both of these legal bases to date.

The European investigation order cannot be used to request the setting up of a JIT.

JITs can also be set up on the basis of other international instruments, particularly with and between competent authorities of States outside the European Union. The following instruments include a legal basis for setting up JITs:

- Agreement between the European Union and the Republic of Iceland and the Kingdom of Norway on the application of certain provisions of the Convention of 29 May 2000 on Mutual Assistance in Criminal Matters between the Member States of the European Union and the 2001 Protocol thereto;

- Article 5 of the Agreement on Mutual Legal Assistance between the European Union and the United States of America;

- Article 27 of the Police Cooperation Convention for South-East Europe (PCC-SEE), applicable between several Member States (Austria, Bulgaria, Hungary, Romania, Slovenia) and countries of the Balkans (Albania, Bosnia and Herzegovina, FYROM, Moldova, Montenegro, Serbia);

- Article 20 of the Second Additional Protocol to the European Convention on Mutual legal Assistance;

- Article 9 of the United Nations Convention against Illicit Traffic in Narcotic Drugs and Psychotropic Substances;

- Article 19 of the United Nations Convention against Transnational Organised Crime (UNTOC);

- Article 49 of the United Nations Convention against Corruption (UNCAC);

- Bilateral agreements between the States involved. 
Not all of the above instruments are applicable between the same States. Therefore, referring to several of these legal bases in the JIT agreement may be necessary in JITs that non-EU States are involved. Furthermore, the content of the provisions related to JITs, which may vary from one instrument to another, may justify that specific arrangements - supplementing the applicable instrument(s) - are introduced in the JIT agreement itself.

Conclusions from the 10th annual meeting of JITs experts can be consulted to get an overview of the specific challenges of JITs involving non-EU States and possible solutions.

Practical considerations. Apart from legal requirements, practical considerations are taken into account in practice when assessing the need for a JIT, some of which are provided below:

- The complexity and sophistication of the criminal network/activities under investigation,

- The number and complexity of investigative measures to be carried out in the States involved, and

- The degree of connection of the investigation between States involved.

In the vast majority of cases for which JITs are established, parallel investigations are ongoing in the concerned States. However, investigations may not always have been opened in all concerned States when a JIT is considered (but only in one or several of them). In such situations, the first step is often to trigger the opening of domestic investigations in the other concerned States. When already ongoing, the respective stage of national investigations can play a role: in particular, national authorities may be more inclined to engage in a JIT when their investigation is still at a relatively preliminary stage and when investigations carried out in other countries are at an equivalent stage. When the case presents connections between more than two countries, their respective level of involvement is also taken into account: sometimes it is agreed as a first step that a JIT will not be established between all countries concerned but between the most involved ones, while the cooperation of others will be sought via MLA. In case one or several countries would like to join the JIT at a later stage, it is always possible to amend the initial agreement. Having this in mind, it is recommended that law enforcement and judicial authorities from the States considering the creation of a JIT meet to discuss the matter at the earliest opportunity before a formal proposal and agreement is made. Eurojust and Europol can play a key role in this respect by allowing - during operational or coordination meetings - national authorities:

- To get a more complete international picture of the case,

- To discuss the advisability and modalities of opening parallel investigations, with a view of settingup a JIT, and

- To clarify domestic requirements concerning the submission of a formal request to set-up a JIT (which in some States constitutes a prerequisite to its setting up).

The JIT agreement. A model agreement has been developed to facilitate the setting up of JITs. This document can be downloaded, in all official languages and in editable format, on the websites of Eurojust and Europol. The JIT model agreement represents a common non-binding baseline that practitioners can tailor to the specific needs of a case. Hence, standard provisions are sometimes reworded to reflect the requirements of national legislation or ad hoc arrangements. The model agreement also provides a useful list covering most of the points that need to be addressed for a JIT to perform its activities in a secure manner. In practice, the EU model is used in the vast majority of JITs set up between EU Member States. Furthermore, this model has proven to be sufficiently flexible to serve as a basis for discussions with non-EU States with some adaptation to the different legal bases. Some Member States have also developed bilateral model agreements that may be helpful in anticipating issues that are likely to arise in this specific context and speed up discussions on the content of the JIT agreement. After an agreement is reached in principle to establish a JIT, Eurojust can provide assistance in drafting the JIT agreement and discussing - via the National Members of the Member States involved - clauses required to supplement or to deviate from the model agreement. A best practice in this respect consists of completing the model agreement in a common working language and translating it in the official languages of the Member States involved only when the partners have agreed on the content of the document. During the lifetime of the JIT, the initial agreement can be amended by mutual agreement between the parties in the event a change in content is needed (e.g. changes in crimes investigated, involvement of a new party, composition of the team, purposes or extension of duration).

Composition of the team. Each party to the JIT agreement appoints the following persons:

- The JIT leader(s), in charge in particular of supervising JIT activities when the team operates on the territory of the concerned State. National legislations usually specify which authority is competent to 
establish a JIT (where applicable, following an authorisation mechanism) and which authority is competent to act as a JIT leader

- The JIT members - in most cases law enforcement authorities- who will perform the investigative measures/operational activities. When present and taking part in investigation outside of their State of origin, appointed members operate with the status of 'seconded JIT members'.

A JIT can be established between competent authorities of at least two States. In practice, it is not rare that JITs are set up between a higher numbers of partners, which may justify that specific arrangements are taken to facilitate the exchange of information and evidence.

Planning and coordination of operational activities. To achieve their purposes, JITs require the effective coordination of domestic proceedings and planning of investigative/prosecutorial steps. Coordination and planning also facilitate requests for financial support, which are based on the estimated costs of planned operational activities. For these reasons, practitioners have identified the need to address these practicalities within the team and to agree on specific arrangements. A checklist has been developed so that arrangements taken can be included in a dedicated document, if deemed appropriate (a so-called 'operational action plan'). However, in practice, a clear preference for more informal solutions has been reported. Periodic meetings -particularly those supported by Eurojust and Europol - are used as planning tools. Conclusions of the meetings reflect the arrangements made. Whatever format is found preferable, discussion and, if possible, recording practical arrangements concerning JIT operational activities that are not already set out in the JIT agreement are recommended.

\section{CONCLUSION}

A JIT is set up for a limited duration that can be prolonged if needed, as agreed by the partners. Partners are recommended to consult and coordinate in due time on a possible extension to avoid discontinuity in the cooperation framework. Unilateral decisions to leave an ongoing JIT should be avoided if possible. Special attention should be given to situations in which, due to different timeframes, the competent authorities of one State need to conclude their investigation - and therefore to put an end to their involvement in a JIT - while cooperation needs still exist from the other partners. According to the feedback received, this issue should be adequately anticipated and ad hoc solutions may need to be found. At the latest before the closure of the JIT18, settlement of jurisdiction and practical steps related thereto (e.g. review of the scope of respective proceedings, sharing and/or possible transfer of jurisdiction, etc.) may need to be considered among JIT partners, although the arrangements taken can be implemented after the closure of the JIT. Evaluation of the JIT by the actors involved is of crucial importance to enhance knowledge and to improve the functioning of the tool. A JIT Evaluation Form has been developed to assist practitioners in this process. When the JIT is due to expire, practitioners are encouraged to jointly perform this evaluation, ideally during a dedicated meeting. Evaluation is required for JITs having received financial support from Eurojust. Detailed information and guidance on the evaluation of JITs and support that can be provided to practitioners can be found here (Hristov, 2018a, pp.61-67; Hristov, Radulov, Iliev, Andreeva, 2010a; Hristov, 2018b, pp. 183-186; Hristov, Ninov, 2018c, pp.316-323; Hristov, Naplatanova, 2018d, pp. 293-315; Hristov, 2017a, pp. 998-1004, Hristov, Georgiev, 2017b, , pp. 110 -113; Hristov, Georgiev, 2017c, , pp. 114-117; Hristov, Glushkov, 2018e, pp.582588; Hristov, Glushkov, 2018f, pp. 187-193; Hristov, 2017d, pp. 821-829; Madanski, Georgiev, 2017e, pp. 413; Madanski, Georgiev, 2017f, pp. 43-51; Terziev, Madanski, Georgiev, 2017g pp. 748-753; Terziev, Madanski, Georgiev, 2017h pp. 743-747; Terziev, Madanski, Georgiev, 2017i pp. 923-927; Terziev, Madanski, Georgiev, 2017j, pp. 1051-1055; Terziev, Nichev, Bankov, 2016a, s.189-196; Terziev, Nichev, Bankov, 2016b, s. s.116-134; Terziev, Nichev, Bankov, 2016c, pp.12-21; Terziev, Nichev, Bankov, 2016d, str.119-128; Terziev, Nichev, Bankov, 2016e, str.129-146; Terziev, Nichev, Bankov, 2016e, str.129-146; Terziev, Nichev, Bankov, 2016f, str. 144-185; Terziev, Nichev, Bankov, 2016f, str. 144-185; Terziev, Nichev, Bankov, 2016g, s.413-422; Terziev, Nichev, Bankov, 2016h, str.177-204; Nichev, 2017k, str. 121-128; Nichev, 2017I, pp. 129-135; Kanev, Terziev. 2017m; Kanev, Terziev, 2017n; Terziev, 2017o; Terziev, 2016i; Terziev, 2017p; Terziev, 2017q; Terziev, Vezieva, Arabska, 2016j; Terziev, Manolov, 2016k; Terziev, Minev, Sotirov, Ivanov, 2016I; Terziev, Kanev, 2017r; Terziev, Madanski, 2017s; Terziev, Madanski, 2017t; Terziev, Madanski, 2017u; Terziev, Madanski, Kanev, 2017v; Terziev, Madanski, Kanev, 2017w; Terziev, Madanski, Kanev, 2017x; Terziev, Madanski, Kanev, 2017y; Terziev, Madanski, Kanev, 2017z; Terziev, Nichev, 2016m; Terziev, Nichev, 2017). 


\section{REFERENCE LIST}

Hristov, Neno. (2018a). Military Education as Possibility in Bulgaria. IJAEDU- International E-Journal of Advances in Education, Vol. IV, Issue 10, April 2018, pp.61-67.

Hristov, N., Radulov, I., lliev, P., Andreeva, P. (2010a). Prioritization Methodology for Development of Required Operational Capabilities. RTO-MP-SAS-081, 2010.

Hristov, Neno. (2018b). NATO Resilience, Deter and Professional Military Education. Proceedings of INTCESS 2018- 5th International Conference on Education and Social Sciences 5-7 February 2018Istanbul, Turkey, pp. 183-186.

Hristov, N, Ninov, M. (2018c). People's Character As a Prerequisite for the Albanian 'National Delay'. // 5th International Conference on Education, Social Sciences and Humanities, 2-4 July, 2018, ISBN: 978605-82433-3-0 316, pp.316-323.

Hristov, N, Naplatanova, G. (2018d). The Stereotypes of Military Towards Journalists and Work with Embedded Reporters in Missions and Operations Abroad. // 5th International Conference on Education, Social Sciences and Humanities, 2-4 July, 2018 - Dubai, ISBN: 978-605-82433-3-0, pp. 293-315.

Hristov, Neno. (2017a). Bulgarian Experience in the Development of Military Concepts. // IJASOSInternational E-Journal of Advances in Social Sciences, Vol. III, Issue 9, December 2017, pp. 9981004.

Hristov, N., Georgiev, M. (2017b). Offset implementation impact on technology transfer in Bulgaria. // International Scientific Journal "Internauka”. Izdatel' OOO «Finansovaya Rada Ukrainy», Kiyev, № 10 (32), 2017, pp. 110 -113, ISSN 2520-2057 (Hristov, N., Georgiev, M. Offset implementation impact on technology transfer in Bulgaria. // International Scientific Journal "Internauka". Издатель ООО «Финансовая Рада Украины», Киев, № 10 (32), 2017, pp. 110 -113, ISSN 2520-2057).

Hristov, N., Georgiev, M. (2017c). Offset as an economic operation and a trade practice. // International Scientific Journal "Internauka”. Izdatel' OOO «Finansovaya Rada Ukrainy», Kiyev, № 10 (32), 2017, pp. 114-117, ISSN 2520-2057 (Hristov, N., Georgiev, M. Offset as an economic operation and a trade practice. // International Scientific Journal "Internauka". Издатель ООО «Финансовая Рада Украины», Киев, № 10 (32), 2017, pp. 114-117, ISSN 2520-2057).

Hristov, N., Glushkov, P. (2018e). Comparative Analysis of the Management Activity Training Of the Cadets, Studying in the Logistic Specializations. // Proceedings of INTCESS2018- 5th International Conference on Education and Social Sciences 5-7 February 2018- Istanbul, Turkey, pp.582-588.

Hristov, N., Glushkov, P. (2018f). Some Aspects Regarding the Display of the Organizational Activity at Work of the Logistic Officers. // Proceedings of INTCESS2018- 5th International Conference on Education and Social Sciences 5-7 February 2018- Istanbul, Turkey, pp.187-193.

Hristov, Neno. (2017d). Policy for Implementation of the Enterprise Architecture as a Tool in Bulgarian Mod. // The University of Sydney, 'History, Problems and Prospects of Development of Modern Civilization' The XX International Academic Congress (Australia, Sydney, 18-20 July 2017) Papers and commentaries Volume XX, ISBN: 978-0-578-84563-7, pp. 821-829.

Madanski, V., Georgiev, M. (2017e). The offset as a specific sort of economic activity. // Scientific journal «Economics and finance». Academic publishing house of the Agricultural University, Priority research areas: Collection of scientific articles, 2017, pp. 4-13, ISBN 978-617-7214-53-2.

Madanski, V., Georgiev, M. (2017f). Study of the effect of offset implementation on technology transfer in the Republic of Bulgaria. // Scientific journal «Economics and finance». Academic publishing house of the Agricultural University, Priority research areas: Collection of scientific articles, 2017, pp. 43-51, ISBN 978-617-7214-53-2.

Terziev, V., Madanski, V., Georgiev, M. (2017g). Offset as an economic operation and a trade practice. // Proceedings of ADVED 2017- 3rd International Conference on Advances in Education and Social Sciences 9-11 October 2017- Istanbul, Turkey. International Organization Center of Academic Research, www.ocerint.org, 2017, pp. 748-753, ISBN: 978-605-82433-0-9.

Terziev, V., Madanski, V., Georgiev, M. (2017h). Offset implementation impact on technology transfer in Bulgaria. // Proceedings of ADVED 2017- 3rd International Conference on Advances in Education and Social Sciences 9-11 October 2017- Istanbul, Turkey .International Organization Center of Academic 
Research, www.ocerint.org, 2017, pp. 743-747, ISBN: 978-605-82433-0-9.

Terziev, V., Madanski, V., Georgiev, M. (2017i). Offset implementation impact on technology transfer in Bulgaria. // IJAEDU- International E-Journal of Advances in Education, International Organization Center of Academic Research, www.ocerint.org, 3, 2017, N 9, pp. 923-927, e-ISSN: 2411-18.

Terziev, V., Madanski, V., Georgiev, M. (2017j). Offset as an economic operation and a trade practice. // IJAEDU- International E-Journal of Advances in Education, International Organization Center of Academic Research, www.ocerint.org, 3, 2017, N 9, pp. 1051-1055, e-ISSN: 2411-18.

Terziev, V., Nichev, N., Bankov, S. (2016a). Corruption and national security. // Mezhdunarodnyy nauchnnyy zhurnal Inovatsionnaya nauka, №10-3/2016, Chastyakh 3, Ufa, Rossiya, ISSN 2410-6070, s.189-196 (Terziev, V., Nichev, N., Bankov, S. Corruption and national security. // Международный научнный журнал Иновационная наука, №10-3/2016, Частях 3, Уфра, Россия, ISSN 2410-6070, с.189-196).

Terziev, V., Nichev, N., Bankov, S. (2016b). Essence and reasons for the manifestation and basic areas of corruption and government structures for corruption counteraction in Bulgaria. // Sbornik nauchnykh trudov „Novyy vzglyad”: Mezhdunarodnyy nauchnyy vestnik: sbornik nauchnykh trudov. Vypusk 15 / Pod obshch. red. S.S. Chernova. - Novosibirsk: Izdatel'stvo TSRNS, 2016. - 166 s., ISBN 978-500068-714-7, s.116-134 (Terziev, V., Nichev, N., Bankov, S. Essence and reasons for the manifestation and basic areas of corruption and government structures for corruption counteraction in Bulgaria. // Сборник научных трудов „Новый взгляд”: Международный научный вестник: сборник научных трудов. Выпуск 15 / Под общ. ред. С.С. Чернова. - Новосибирск: Издательство ЦРНС, 2016. - 166 с., ISBN 978-5-00068-714-7, с.116-134).

Terziev, V., Nichev, N., Bankov, S. (2016c). National security of the republic of Bulgaria. // Science and practice: Collection of scientific articles. Thoroe-Bowker, Melbourne, Australia, 2016, ISBN 978-09942661-3-2, pp.12-21.

Terziev, V., Nichev, N., Bankov, S. (2016d). Tipichni modeli na razsledvanena koruptsiyata sred politseyski sluzhiteli. // Sbornik dokladi: Godishna universitetska nauchna konferentsiya, 20-21 oktomvri 2016 g., NVU „Vasil Levski“ - Veliko Tarnovo., Nauchno napravlenie „Sotsialni, stopanski i pravni nauki“, 7, 2016, ISSN 1314-1937, str.119-128 (Терзиев, В., Ничев, Н., Банков, С. Типични модели на разследванена корупцията сред полицейски служители. // Сборник доклади: Годишна университетска научна конференция, 20-21 октомври 2016 г., НВУ „Васил Левски“ - Велико Търново., Научно направление „Социални, стопански и правни науки“, 7, 2016, ISSN 1314-1937, стр.119-128).

Terziev, V., Nichev, N., Bankov, S. (2016e). Nakazatelno pravni aspekti na koruptsiyata i ustanoveni praktiki v Balgariya. // Sbornik dokladi: Godishna universitetska nauchna konferentsiya, 20-21 oktomvri 2016 g., NVU „Vasil Levski“ - Veliko Tarnovo., Nauchno napravlenie „Sotsialni, stopanski i pravni nauki“, 7 , 2016, ISSN 1314-1937, str.129-146 (Терзиев, В., Ничев, Н., Банков, С. Наказателно правни аспекти на корупцията и установени практики в България. // Сборник доклади: Годишна университетска научна конференция, 20-21 октомври 2016 г., НВУ „Васил Левски“ - Велико Търново., Научно направление „Социални, стопански и правни науки“, 7, 2016, ISSN 1314-1937, стр.129-146).

Terziev, V., Nichev, N., Bankov, S. (2016f). Prilozhenie na efektivna metodika na razsledvane na koruptsiyata sred politseyskite sluzhiteli v Balgariya. // Godishnik na NVU „Vasil Levski“, NVU „Vasil Levski“- Veliko Tarnovo, Izdatelski kompleks na NVU „Vasil Levski”, 2015, ISSN 1312-6148, str.144185 (Терзиев, В., Ничев, Н., Банков, С. Приложение на ефективна методика на разследване на корупцията сред полицейските служители в България. // Годишник на НВУ „Васил Левски“, НВУ „Васил Левски“- Велико Търново, Издателски комплекс на НВУ „Васил Левски”, 2015, ISSN 1312-6148, стр.144-185).

Terziev, V., Nichev, N., Bankov, S. (2016g). Razrabotvane na metodika na razsledvane na koruptsiyata sred politseyskite sluzhiteli v Balgariya. // XI Mezhdunarodnoy nauchnoy konferentsii „Innovatsii v tehnologiyah i obrazovanii“, 18-19 Marta 2016 g., Sbornik statey: chasty 3, Belovo- Veliko-tayrnovo, 2016, Kuzbasskiy gosudarstvennayy tehnicheskiy universitet imeni T.F. Gorbacheva Velikotayrnovskiy universitet im. Svyatayh. Kirilla i Mefodiya Filial KuzGTU v g. Belovo Vaysshaya shkola agrobiznesa i razvitiya regionov, Plovdiv, 2016, s.413-422, ISBN 978-5-906888-03-7 (Терзиев, В., Ничев, Н., Банков, С. Разработване на методика на разследване на корупцията сред полицейските служители в България. // XI Международной научной конференции „Инновации в технологиях и образовании“, 18-19 Марта 2016 г., Сборник статей: часть 3, Белово- Велико-тырново, 2016, 
Кузбасский государственный технический университет имени Т.Ф. Горбачева Великотырновский университет им. Святых. Кирилла и Мефодия Филиал КузГТУ в г. Белово Высшая школа агробизнеса и развития регионов, Пловдив, 2016, с.413-422, ISBN 978-5-906888-03-7).

Terziev, V., Nichev, N., Bankov, S. (2016h). Prilozhenie na efektivna metodika na razsledvane na koruptsiyata sred politseyskite sluzhiteli v Balgariya. // Sbornik dokladi: Parva nauchna konferentsiya po sotsialno predpriemachestvo. Saveti, umeniya i instrumenti za konsultirane na sotsialnite predpriemachi, Proekt : Umeniya za biznes konsultanti v oblastta na sotsialnoto predpriemachestvo, International scientific conference 29 September 2016, Plovdiv, Bulgaria, Agraren Universitet Plovdiv, 2016, ISBN 978-954-517-249-6 (CD), ISBN 978-954-517-250-2 (Print), str.177-204 (Терзиев, В., Ничев, Н., Банков, С. Приложение на ефективна методика на разследване на корупцията сред полицейските служители в България. // Сборник доклади: Първа научна конференция по социално предприемачество. Съвети, умения и инструменти за консултиране на социалните предприемачи, Проект : Умения за бизнес консултанти в областта на социалното предприемачество, International scientific conference 29 September 2016, Plovdiv, Bulgaria, Аграрен Университет Пловдив, 2016, ISBN 978-954-517-249-6 (CD), ISBN 978-954-517-250-2 (Print), стр.177-204).

Nichev, N. (2017k). Ofsetna politika na stranite ot Evropeyskiya Sayuz. Spisanie za nauka „Novo znanie”, Akademichno izdatelstvo „Talant“, Visshe uchilishte po agrobiznes i razvitie na regionite, Plovdiv, Vol 6, No 1, 2017, str. 121-128, ISSN 2367-4598 (Online), ISSN 1314-5703 (Print) (Ничев, Н. Офрсетна политика на страните от Европейския Съюз. Списание за наука „Ново знание”, Академично издателство „Талант“, Висше училище по агробизнес и развитие на регионите, Пловдив, Vol 6, No 1, 2017, стр. 121-128, (Online) ISSN 2367-4598, (Print) ISSN 1314-5703).

Nichev, N. (2017l). Perspektivi za izpolzvane na ofsetnite sdelki. Spisanie za nauka "Novo znanie”, Akademichno izdatelstvo „Talant“, Visshe uchilishte po agrobiznes i razvitie na regionite - Plovdiv, Vol 6, No 1, 2017: pp. 129-135, (Online) ISSN 2367-4598, (Print) ISSN 1314-5703 (Ничев, Н. Перспективи за използване на офсетните сделки. Списание за наука „Ново знание”, Академично издателство „Талант“, Висше училище по агробизнес и развитие на регионите Пловдив, Vol 6, No 1, 2017: pp. 129-135, (Online) ISSN 2367-4598, (Print) ISSN 1314-5703).

Kanev, D.,Terziev. V. (2017m). Behavioral economics: development, condition and perspectives. // IJASOSInternational E-Journal of Advances in Social Sciences, Vol. III, Issue 8, e-ISSN: 2411-183X.

Kanev, D.,Terziev. V. (2017n). Behavioral economics: development, condition and perspectives. // Proceedings of SOCIOINT 2017- 4th International Conference on Education, Social Sciences and Humanities 10-12 July 2017- Dubai, UAE, ISBN: 978-605-82433-1-6.

Sotirov, B., Terziev, V. (2015a). Predizvikatelstva i perspektivi pred obuchenieto po tehnologichni distsiplini. // Parva mezhdunarodna nauchna konferentsiya „Predizvikatelstva pred savremennite organizatsii, svarzani s postigane na ustoychivost - znanie i inovatsii v upravlenieto i funktsioniraneto",Plovdiv. ISBN 978-619-7246-04-9 (DVD), ISBN 978-619-7246-06-3 (e-book).

Sotirov, B., Terziev, V. (2015b). Challenges and perspectives to the training in technological subjects. // Book of Abstracts: First International Scientific Conference "Sustainability Challenges in Modern Organizations - Knowledge \& Innovation in Management \& Operation", ISBN 978-619-7246-03-2 (DVD), ISBN 978-619-7246-05-6 (e-book).

Terziev. V. (20170). National security of the republic of Bulgaria. // The Chinese Journal of International Politics, №1(10), ISSN 1750-8916.

Terziev. V. (2016i). Human resource management systems in security and defense: social policies for social activities. // XXXII Mezhdunarodnaya nauchno-prakticheskaya konferentsiya, Evraziyskiy soyuz uchenayh (ESU), Ezhemesyachnayy nauchnayy zhurnal № 12 (33)/ 2016 Chasty 1, Moskva 30.12.2016g., ISSN 2411-6467.

Terziev. V. (2017p). Entry Opportunities in the Bulgarian Military - Educational System and Ensuring of Civil Rights. // 3rd Central and Eastern European LUMEN International Scientific Conference New Approaches in Social and Humanistic Sciences 8-10 June 2017 | Chisinau, Republic of Moldova, ISBN: 978-973-166-461-3.

Terziev. V. (2017q). National security of the republic of Bulgaria. // International Journal of Management and Applied Science, Volume-3, Issue-4, ISSN: 2394-7926.

Terziev, V., Vezieva. V., Arabska, A. (2016j). Balgarskite universiteti i vazmozhnostite na Operativna 
programa „Nauka i obrazovanie za inteligenten rastezh". // Mezhdunarodna nauchna konferentsiya „Obrazovanie, nauka, ikonomika i tehnologii“ 23-24 yuni 2016 g. Akademichno spisanie „Upravlenie i obrazovanie“ Tom XII(1) 2016, ISSN 1312-6121.

Terziev, V., Manolov.D. (2016k). Sazdavane na dobra organizatsionna sreda za nauchnoizsledovatelska deynost (Creation of good organizational environment for scientific research activity), Aktual'nyye problemy globalizatsii. // Saloniki, Gretsiya (Actual problems of globalization, August 29, 2016, Thessaloniki, Greece), Scientific journal „ECONOMICS AND FINANCE“, Actual problems of globalization - Collection of scientific articles, ISBN 978-617-7214-34-1.

Terziev, V., Minev, R., Sotirov, B., Ivanov, K. (2016l). Vazmozhnosti za izgrazhdane na tsentar za kompetentnost $v$ Severen tsentralen rayon na Republika Balgariya. // Godishna universitetska nauchna konferentsiya, 20-21 oktomvri 2016 g. NVU „Vasil Levski“- Veliko Tarnovo. Sbornik dokladi tom 2, Nauchni napravleniya „Prirodomatematicheski nauki” i „Tehnicheski nauki”, ISSN 1314-1937.

Terziev. V., Kanev, D. (2017r). Education and Behavioural Failures. // Proceedings of ADVED 2017- 3rd International Conference on Advances in Education and Social Sciences 9-11 October 2017- Istanbul, Turkey, ISBN: 978-605-82433-0-9.

Terziev, V, Madanski, V. (2017s). Development of military education system in Bulgaria (Razvitie na voennoobrazovatelnata sistema $v$ Balgariya). // Topical questions of contemporary science, United States of America 2017, ISBN 978-0-9988732-1-3.

Terziev, V, Madanski, V. (2017t). Guidelines for development of military education system in Bulgaria (Nasoki za razvitie na voennoobrazovatelnata sistema na Balgariya). // Topical questions of contemporary science, United States of America 2017, ISBN 978-0-9988732-1-3.

Terziev, V, Madanski, V. (2017u). Guidelines for development of military education system in Bulgaria. // Proceedings of the VII International Academic Congress "Fundamental and Applied Studies in EU and CIS Countries” (United Kingdom, Cambridge, England, 26-28 February 2017). Volume VII. Cambridge University Press, 2017, ISBN: 978-0-875-83597-4.

Terziev, V, Madanski, V., Kanev, D. (2017v). Entry opportunities in the bulgarian military-educational system and ensuring of civil rights. // Proceedings of SOCIOINT 2017- 4th International Conference on Education, Social Sciences and Humanities 10-12 July 2017- Dubai, UAE, ISBN: 978-605-82433-1-6.

Terziev, V, Madanski, V., Kanev, D. (2017w). Entry opportunities in the bulgarian military-educational system and ensuring of civil rights. // IJAEDU- International E-Journal of Advances in Education, Vol. 3, Issue 8, August 2017, e-ISSN:2411-1821.

Terziev, V, Madanski, V., Kanev, D. (2017x). Entry opportunities in the Bulgarian military-educational system. // Sport, Education and Society, Issue 8 (2), Volume 22. Taylor \& Francis, Print ISSN: 1357-3322 Online ISSN: $1470-1243$.

Terziev, V, Madanski, V., Kanev, D. (2017y). Condition and capabilities of the military-educational system of the Republic of Bulgaria. // Sport, Education and Society, Issue 8 (2), Volume 22. Taylor \& Francis, Print ISSN: 1357-3322 Online ISSN: 1470-1243.

Terziev, V, Madanski, V., Kanev, D. (2017z). Directions for improvement of the military-educational system and its contribution for strengthening national security and the defence of the country. // Sport, Education and Society, Issue 8 (2), Volume 22. Taylor \& Francis, Print ISSN: 1357-3322 Online ISSN: 1470-1243.

Terziev, V., N.Nichev. (2016m). Ikonomicheski harakteristiki na ofestnite sdelki s otrbranitelni produkti. // Scientific journal „Economics and Finance”, Problems of development modern science: Theory and practice - Collection of scienfic articles, pp.101-106.

Terziev. V., N.Nichev. (2017). Osnovni harakteristiki na kompensaciite v tyrgoviqta s otbrana. // Proceedings of SOCIOINT 2017- 4th International Conference on Education, Social Sciences and Humanities, pp.661-666. 